\title{
“I'm Not Happy, But I Don't Care": Help-Seeking Behavior, Academic Difficulties, and Happiness
}

\author{
Hong-Im Shin ${ }^{1}$ and Woo Taek Jeon ${ }^{2}$ \\ ${ }^{1}$ BK 21 Project for Psychology and ${ }^{2}$ Department of Medical Education, Yonsei University College of \\ Medicine, Seoul, Korea
}

Purose: Medical education is perceived as being very stressful, which leads to declines in subjective well-being in medical students. Therefore, student counseling is becoming an exigent issue. The goal of this study was to investigate the academic difficulties and subjective well-being of medical students to identify their needs with regard to counseling. In addition, we analyzed help-seeking behaviors of students to develop an effective counseling program.

Methods: We performed a survey $(n=205)$ to determine the extent to which medical students encounter academic difficulties in their lives in medical school and how they attempt to resolve their problems. In addition, we used the Oxford Happiness Scale to examine the relationships between academic performance, previous help-seeking behavior, and happiness in medical students.

Results: Of various types of problems, $62 \%$ of medical students perceived learning difficulties to be the most serious issue in medical school. Despite encountering difficulties, more than $67 \%$ of students failed to seek help from faculty or their fellow students. There was a significant relationship between happiness score and previous help-seeking behavior. A lack of perceived seriousness was identified as the most significant barrier to seeking help.

Conclusion: Access to counseling programs must be improved for students with apparent academic difficulties who do not seek counseling. Through such programs, students can learn and practice methods of coping with their difficulties and develop medical and professional competence.

Key Words: Help-seeking behavior, Learning disorders, Happiness, Medical students, Counseling

\section{INTRODUCTION}

There is a high prevalence of studies that illustrate that medical education is very stressful [1,2,3]. Workload, fears of failing exams and a highly competitive atmosphere are commonly related to learning in medical school. Research shows that depression and stress of medical students are of serious concern $[4,5,6,7]$. In addition, some students experience severe academic difficulties, even if they have the intellect to successfully complete medical school. According to reports
Received: August 20, 2010 • Revised: October 18, 2010 • Accepted: November 12, 2010 Corresponding Author: Woo Taek Jeon

Department of Medical Education, Yonsei University College of Medicine, 262 Seongsanno, Seodaemungu, Seoul 120-749, Korea

Tel: +82.2.2228.2510 Fax: +82.2.364.5450 email: wtjeon@yuhs.ac
Korean J Med Educ 2011 Mar; 23(1): 7-14. doi: 10.3946/kjme.2011.23.1.7. pISSN: 2005-727X eISSN: 2005-7288

(C) The Korean Society of Medical Education. All rights reserved. This is an open-access article distributed under the terms of the Creative Commons Attribution Non-Commercial License (http:// creativecommons.org/licenses/by-nc/3.0/), which permits unrestricted non-commercial use, distribution, and reproduction in any medium, provided the original work is properly cited. 
Hong Im Shin and Woo Taek Jeon : "I'm Not Happy, But I Don't Care": Help-Seeking Behavior, Academic Difficulties, and Happiness

of medical education counselors, the causes of academic failures are varied $[8,9]$. Some students have a low level of learning and time managing skills, while others have personal difficulties, financial reasons or emotional problems. Therefore it's very critical to identify causes of learning problems and to draw up individual action plans to cope with academic failures successfully.

However students at risk seldom seem to seek help, even though they have problems with academic performance and psychological wellbeing $[6,8,9,10,11,12,13]$. They often don't feel responsible for seeking help and don't try to identify their learning needs [8]. Therefore it's not only the problem in itself but rather the passiveness in dealing with the problem that needs to be addressed. Previous research among college students report common barriers to help seeking such as lack of time, privacy concerns, lack of emotional openness and negative attitudes toward counseling $[12,14,15]$. However these findings mostly from small samples of students have limitations, in so far as that they just describe low help seeking behaviors of students with poor performance but don't show any relationships between help-seeking behaviors, academic difficulties and subjective well-being. A better understanding of what factors affect help-seeking and subjective wellbeing of students and why they are reluctant to access counseling is essential for designing and implementing effective student support programs.

To answer these questions, this study covered three key areas: The first goal was to explore academic difficulties and subjective wellbeing of medical students to analyze their need for counseling. In addition, we investigated the relationships between academic performance, happiness, and previous help seeking behaviors of students. Finally, we tried to identify barriers to use academic counseling programs.

\section{SUBJECTS AND METHODS}

The study population consisted of medical students at Yonsei University during the spring of 2010. Of the 360 students in the target population, 205 students (56.9\%) returned the questionnaires. Of the 205 students who responded, 130 students (63.4\%) were men and 75 (36.5\%) were women. The age ranged from 19 to 30 $(\mathrm{M}=22.9, \mathrm{SD}=1.93)$ years. They were first-year to thirdyear medical students (M1, n=80; M2, n=71; M3, n=54). We constructed our questionnaire to identify types of difficulties in their college life, perceived need for counseling, help-seeking behaviors, barriers to use counseling programs and demographic data including age, gender, self reported academic performance according to percentile rank (high, 67 100\%; moderate, 34 66\%; low, 1 33\%) and experience of failing in exams. A need for academic counseling was self-rated on a five-point Likert scale. It varied from hardly needed' to 'highly needed.'

Additionally the Oxford Happiness Questionnaire (OHQ) [16] was used to quantify psychological wellbeing of medical students. The OHQ was carried out in English and consisted of single statements, which only require a basic level of English proficiency. It comprises 29 items, which can be answered on a six-point Likert scale ranging from 'strongly agree' to 'strongly disagree.' Items of the OHQ cover seven subscales such as self esteem ("I feel pleased with the way I am"), sense of control ("I usually have a good influence on events"), social interest (" $\mathrm{I}$ am intensely interested in other people"), positive affect ("I laugh a lot"), physical fitness (“I feel healthy”), mental alertness (“I feel fully mentally alert") and aesthetic appreciation ("I find beauty in some things"). The reliability (Cronbach $\alpha$ ) of the OHQ was $0.91[16]$. 


\section{RESULTS}

\section{Types of difficulties}

Among various types of difficulties, learning difficulties were most often perceived as a serious problem. More than $60 \%$ of students reported their academic problems are quite severe (Table 1). Other concerns regarding interpersonal problems $(12.1 \%)$ and career choice (17.0\%) were not very commonly reported. Worries about interpersonal problems were more frequently mentioned among female students than male students, whereas concerns about career choice were perceived as more serious among male students than among female students. However male and female students reported most frequently that they are confronted with academic difficulties. In spite of perceived learning problems, just $34.1 \%$ of medical students requested help. The other students (65.9\%) didn't seek any help, even if they were aware of academic difficulties. There were no gender differences in help-seeking behavior $\left(x^{2}=3.961, p=0.468\right)$. Male and female students didn't seek support, even if they perceived their problems.

\section{Academic performance, happiness, and perceived need for counseling}

Table 2 shows the comparisons of happiness and

\section{Table 1. Types of Difficulties among Medical Students}

\begin{tabular}{|c|c|c|c|c|c|c|c|c|}
\hline \multirow[t]{2}{*}{ Types of difficulties } & \multicolumn{3}{|c|}{ Frequency, №. $|\%|$} & \multirow[t]{2}{*}{$x^{2}(p)$} & \multicolumn{3}{|c|}{$\begin{array}{l}\text { Previous use of counseling, } \\
\text { given a perceived need, №. (\%) }\end{array}$} & \multirow[t]{2}{*}{$x^{2}(p)$} \\
\hline & Male & Female & Total & & Male & Female & Total & \\
\hline Learning difficulties & 81 & 48 & $129(62.9)$ & \multirow{6}{*}{$\begin{array}{l}x^{2}=13.02 * * a \mid \\
d f=4 \\
p=0.008\end{array}$} & 24 & 20 & 44 (34.1) & \multirow{6}{*}{$\begin{array}{l}x^{2}=3.961 \\
d f=4 \\
p=0.411\end{array}$} \\
\hline Interpersonal problems & 11 & 14 & $25(12.1)$ & & 4 & 2 & $6(24.0)$ & \\
\hline Career choice & 30 & 5 & $35(17.1)$ & & 12 & 1 & $13(37.1)$ & \\
\hline Physical health & 4 & 8 & $12(5.9)$ & & 2 & 0 & 2 (16.6) & \\
\hline Partnership problems & 4 & 0 & $4(2.0)$ & & 1 & 0 & $1(25.0)$ & \\
\hline Total & 130 & 75 & $205(100.0)$ & & 43 & 23 & $66(32.1)$ & \\
\hline
\end{tabular}

${ }^{* *} \mathrm{p}<0.01$.

a) Three cells (30\%) have an expected value of less than 5 . Therefore Fisher's exact test was conducted. The Fisher's exact test value was 12.32, and the p-value was 0.010 .

Table 2. Perceived Need for Counseling, Happiness, and Academic Performance

\begin{tabular}{rcrrrrrrrrr}
\hline & $\begin{array}{c}\text { Academic } \\
\text { performance }\end{array}$ & No. & M & SD & $\begin{array}{c}\text { Source of } \\
\text { variation }\end{array}$ & $\begin{array}{r}\text { Sum of } \\
\text { square }\end{array}$ & df & $\begin{array}{r}\text { Mean } \\
\text { square }\end{array}$ & p & pvalue \\
\hline Perceived need & SH & 53 & 3.13 & 1.05 & Between groups & 3.99 & 2 & 1.99 & 2.03 & 0.134 \\
for counseling & SM & 76 & 2.92 & 0.96 & Within groups & 173.75 & 177 & 0.98 & & \\
& SL & 51 & 3.27 & 0.96 & Total & 177.75 & 179 & & & \\
Happiness & SH & 51 & 3.80 & 0.56 & Between groups & 3.22 & 2 & 1.61 & $4.70^{*}$ & 0.01 \\
& SM & 73 & 3.89 & 0.62 & Within groups & 57.80 & 169 & 0.34 & & \\
& SL & 48 & 4.14 & 0.53 & Total & 61.02 & 171 & & & \\
\hline
\end{tabular}

SD: Standard deviation, SH: Students with high academic performance, SM: Students with moderate academic performance, SL: Students with poor academic performance.

${ }^{*} p<0.05$. 
Hong Im Shin and Woo Taek Jeon : "I'm Not Happy, But I Don't Care": Help-Seeking Behavior, Academic Difficulties, and Happiness

perceived need for counseling between students with high, moderate and low academic performance. Ironically, students with low academic performance reported significantly higher happiness scores than students with high academic performance $(\mathrm{F}=4.70$, $\mathrm{p}=0.01$ ). In addition, they didn't perceive much higher need for counseling, even though they reported low academic performance. However these students with low

$\overline{\text { Table 3. Characteristics of Students with or without Experience of }}$ Failing on Exams

\begin{tabular}{|c|c|c|c|c|}
\hline & \multicolumn{2}{|c|}{$\begin{array}{l}\text { Students without } \\
\text { experiences of failing } \\
\text { on exams ( } n=191 \text { ) }\end{array}$} & \multicolumn{2}{|c|}{$\begin{array}{l}\text { Students with } \\
\text { experiences of failing } \\
\text { on exams ( } n=14)\end{array}$} \\
\hline & No. & $\%$ & No. & $\%$ \\
\hline $\operatorname{Age}^{\mathrm{al}}$ & \multicolumn{2}{|c|}{$22.8(1.93)$} & \multicolumn{2}{|c|}{$23.79(2.19)$} \\
\hline \multicolumn{5}{|l|}{ Gender } \\
\hline Male & 116 & 60.7 & 14 & 100.0 \\
\hline Female & 75 & 39.3 & 0 & 0 \\
\hline \multicolumn{5}{|l|}{ Medical school year } \\
\hline First & 75 & 39.3 & 5 & 35.7 \\
\hline Second & 68 & 35.6 & 3 & 21.4 \\
\hline Third & 48 & 25.1 & 6 & 42.9 \\
\hline $\begin{array}{l}\text { Perceived need for } \\
\text { counseling }\end{array}$ & \multicolumn{2}{|c|}{3.04 (0.97) } & \multicolumn{2}{|c|}{3.79 (0.89) } \\
\hline Happiness (overall) & \multicolumn{2}{|c|}{$3.94(0.58)$} & \multicolumn{2}{|c|}{$3.79(0.71)$} \\
\hline
\end{tabular}

a) The values for age, perceived need for counseling, and happiness (overall) are presented as M (SD). academic performance seemed to begin to perceive a need for counseling when they didn't fulfill the minimum requirements and failed in exams. As Table 3 shows, failing students $(n=14,6.5 \%)$ reported a higher need for counseling than other students (M, 3.79 vs. 3.04; $t=2.77 ; p=0.001$ ). This indicates that students with low academic performance require explicit intervention earlier than when they request, because they couldn't perceive a need for counseling until there is clear evidence about their inadequate performance.

\section{Previous help seeking behaviors and barriers to using counseling programs}

Table 4 shows previous help seeking behaviors of students with high, moderate and low academic performance. Students with low academic performance usually sought help from senior fellow students, whereas students with high or moderate academic performance usually sought support from medical faculty. The difference was statistically significant $\left(x^{2}=14.949, \quad p=\right.$ 0.000). Additionally, previous use of counseling was associated with higher happiness scores (Table 5). Students with experiences in seeking help from any source were much happier $(\mathrm{t}=3.22, \mathrm{p}=0.001)$ and perceived a higher need for counseling $(t=2.87, p=0.004)$

Table 4. Help-Seeking Source, Given a Perceived Learning Problem

\begin{tabular}{|c|c|c|c|c|c|}
\hline \multirow{2}{*}{ Academic performance } & \multicolumn{3}{|c|}{ From whom did you seek help? } & \multirow{2}{*}{ Total } & \multirow{2}{*}{$x^{2}(p)$} \\
\hline & Medical faculty staff & Senior students & Fellow students & & \\
\hline$S H+S M^{b l}$ & $12(37.5)$ & $1(3.1)$ & $10(31.3)$ & $23(71.9)$ & $x^{2}=14.949 * * a$ \\
\hline SL & $1(3.1)$ & $6(18.8)$ & $2(6.3)$ & $9(28.1)$ & $\mathrm{df}=2$ \\
\hline Total & $13(40.6)$ & 7 (21.9) & $12(37.5)$ & $32(100.0)$ & $p=0.000$ \\
\hline
\end{tabular}

Values are presented as number $(\%)$.

SH: Students with high academic performance, SM: Students with moderate academic performance, SL: Students with poor academic performance.

${ }^{* *} p<0.01$.

a) Three cells $(50 \%)$ have an expected value of less than 5 . Therefore, Fisher's exact test was conducted. The Fisher's exact test value was 12.89 , and the p-value was $0.001,{ }^{\text {b) }}$ Due to the small sample size, students with high or moderate academic performance were coded as one group. The students with low academic achievement were compared as the other group. 
Hong Im Shin and Woo Taek Jeon : "I'm Not Happy, But I Don't Care": Help-Seeking Behavior, Academic Difficulties, and Happiness

than those who did nothing for their problems. However the difference of perceived need for counseling between students with high and low academic performance was found to be not meaningful $(t=-0.71, p=0.474)$. Therefore

Table 5. Previous Use of Counseling and Happiness among Medical Students

\begin{tabular}{lcrcccc}
\hline \multicolumn{1}{c}{ Subscales } & Previous use of counseling & No. & $\mathrm{M}$ & SD & $\mathrm{t}$ & $\mathrm{p}$-value \\
\hline Self-esteem & Yes & 64 & 3.67 & 0.83 & 0.60 & 0.544 \\
Sense of control & No & 137 & 3.58 & 1.01 & & \\
& Yes & 64 & 4.05 & 0.79 & $2.76^{* *}$ & 0.006 \\
Social interest & No & 137 & 3.66 & 1.00 & & \\
& Yes & 64 & 4.07 & 1.00 & $2.69^{* *}$ & 0.008 \\
Positive affect & No & 137 & 3.65 & 1.01 & & \\
& Yes & 64 & 4.29 & 0.79 & $3.45^{* *}$ & 0.001 \\
Physical health & No & 137 & 3.81 & 0.95 & & \\
& Yes & 64 & 3.90 & 1.62 & $1.96^{*}$ & 0.050 \\
Mental alertness & No & 137 & 3.38 & 1.79 & & \\
& Yes & 64 & 3.68 & 0.99 & 1.60 & 0.110 \\
Aesthetic appreciation & No & 137 & 3.44 & 1.01 & & \\
& Yes & 64 & 4.71 & 1.01 & $3.76^{* * *}$ & 0.000 \\
Happiness (overall) & No & 137 & 4.02 & 1.28 & & \\
& Yes & 64 & 4.12 & 0.71 & $3.22^{* *}$ & 0.001 \\
& No & 137 & 3.80 & 0.60 & & \\
\hline
\end{tabular}

SD: Standard deviation.

${ }^{*} p<0.05,{ }^{* *} p<0.01,{ }^{* * *} p<0.001$.

Table 6. Barriers to Help-Seeking Behaviors, Given a Perceived Problem

\begin{tabular}{|c|c|c|c|c|c|}
\hline Study year & Barriers & $S H+S M^{a l}$ & SL & Total & $x^{2}(p)$ \\
\hline \multirow[t]{5}{*}{1} & I don't think my problem is serious & $25(52.1)$ & $2(4.2)$ & $27(56.3)$ & $x^{2}=7.913^{* b)}$ \\
\hline & I don't know anyone who can understand my problems & $7(14.6)$ & $1(2.1)$ & $8(16.7)$ & $d f=3$ \\
\hline & I don't believe counseling is helpful & $1(2.1)$ & $2(4.2)$ & $3(6.3)$ & $p=0.048$ \\
\hline & I am concerned about privacy & $8(16.7)$ & $2(4.2)$ & $10(20.8)$ & \\
\hline & Total & $41(85.4)$ & $7(14.6)$ & 48 (100.0) & \\
\hline \multirow[t]{5}{*}{2} & I don't think my problem is serious & $18(46.2)$ & $6(15.4$ & $24(61.5)$ & $x^{2}=2.383$ \\
\hline & I don't know anyone who can understand my problems & $4(10.3)$ & $2(5.1)$ & $6(15.4)$ & $d f=3$ \\
\hline & I don't believe counseling is helpful & $6(15.4)$ & $0(0.0)$ & $6(15.4)$ & $p=0.497$ \\
\hline & I am concerned about privacy & $2(5.1)$ & $1(2.6)$ & $3(7.7)$ & \\
\hline & Total & 30 (76.9) & $9(23.1)$ & $39(100.0)$ & \\
\hline \multirow[t]{5}{*}{3} & I don't think my problem is serious & $7(28.0)$ & $4(16.0)$ & $11(44.0)$ & $x^{2}=3.122$ \\
\hline & I don't know anyone who can understand my problems & $3(12.0)$ & $1(4.1)$ & $4(16.0)$ & $d f=3$ \\
\hline & I don't believe counseling is helpful & $2(8.0)$ & $5(20.0)$ & $7(28.0)$ & $p=0.373$ \\
\hline & I am concerned about privacy & $2(8.0)$ & $1(4.0)$ & $3(12.0)$ & \\
\hline & Total & $14(56.0)$ & $11(44.0)$ & $25(100.0)$ & \\
\hline
\end{tabular}

Values are presented as number $(\%)$.

SH: Students with high academic performance, SM: Students with moderate academic performance, SL: Students with low academic performance.

${ }^{*} p<0.05$.

a) Due to the small sample size, students with high or moderate academic performance were coded as one group. The students with low academic achievement were compared as the other group, ${ }^{\text {b) }}$ Five cells $(62.5 \%)$ have an expected value less than 5 . Therefore, Fisher's exact test was conducted. The Fisher's exact test value was 6.368 , and the p-value was 0.05 . 
Hong Im Shin and Woo Taek Jeon : "I'm Not Happy, But I Don't Care": Help-Seeking Behavior, Academic Difficulties, and Happiness

students without previous access to counseling seem not to be able to perceive the need for counseling, even though they have learning difficulties and don't feel happy. This result indicates that previous failure to seek help can preclude students from acknowledging their problems as serious and taking steps to resolve their problems.

Table 6 shows common barriers to using counseling programs. Among these barriers, lack of perceived seriousness was the most common reason for not seeking help. Alarmingly, the reason why students with low academic performance didn't request help seeking was also the lack of perceived seriousness. In addition, there were statistically significant relationships between barriers and academic performance among M1 (first grade) medical students $\left(x^{2}=7.913, p=0.048\right)$. Compared to M1 students with poor academic performance, M1 students with high or moderate academic achievement often reported privacy concerns and usually mentioned that they didn't know to whom to go. The students with low academic performance tended to have a more negative attitude toward the effectiveness of counseling. Among the students with high or moderate academic performance, who didn't go to academic counseling $(\mathrm{n}=85), 10.5 \%$ of students $(\mathrm{n}=9)$ expressed worries about counseling effectiveness. Compared to this, $25.9 \%$ of students $(\mathrm{n}=7)$ in the low achieving group without asking for help $(n=27)$ answered that seeking support would be not helpful.

\section{DISCUSSION}

In our survey, academic difficulties were a major concern among medical students. More than $60 \%$ of medical students perceived learning difficulties as their most serious in college life. However, only $34 \%$ of students reported using counseling programs or getting advice from medical faculty, even if they perceived learning problems. Why didn't they seek professional help? Among common barriers identified from previous studies, a lack of perceived seriousness was the most frequently mentioned reason for not getting help in our survey [11,12]. This reason was also commonly reported among students with poor academic performance. There might be a belief that the problems were not serious, even if they had severe academic difficulties. This result was consistent with previous research, which showed that failing students often regarded themselves as competent learners and they believed that they can overcome academic difficulties easily, if they want [8]. This result highlighted that mandatory counseling programs with explicit and specific feedback should be conducted for students who are not aware of the seriousness of their problems. Through such programs, students could identify their learning needs and practice coping skills to resolve their ongoing difficulties.

Concern about effectiveness of treatment was also a more frequently reported barrier among students with low academic performance, compared to other students with moderate or high academic achievement. Additionally, students with low academic performance tended to be reluctant to access medical staff. This result was consistent with the study of Cleland et al. [8], which showed that most failing students were unwilling to go to medical faculty, because they believed that asking for help has a negative impact on their image and student profiles. This finding indicated that negative attitudes toward academic counseling are quite prevalent among medical students with low academic performance. Therefore campus level intervention and policy should be adopted to change stigmatizing attitude to counseling and to facilitate help seeking behavior of students. First of all, it's important to increase confidentiality of 
counseling with privacy guidelines for counseling records. More importantly, an individually tailored remedial program with the support of senior fellow students is needed for students with severe academic difficulties, who are unwilling to go to medical faculty. Many medical schools operate a personal tutor system for risk students, which contribute to help resolving academic problems [13,17,18].

There are two limitations of this study. One limitation is the relatively low response rate of students. About $40 \%$ of our target population couldn't be considered. Those students might have provided further important information in regard to low help seeking behaviors. Additionally, there are some critical factors, such as causes of academic difficulties, students' self reflection of their learning abilities, motivation to be a good doctor and family background, which weren't investigated in this study. However, such factors might be associated with low help seeking behaviors [8,9]. In future research, relationships between various factors in the help seeking behaviors of medical students should be systematically identified.

Despite of these limitations, this study shows that a lot of medical students are suffering from learning difficulties, but they are not seeking any support. Early intervention will have a positive impact on medical students with ongoing difficulties. To fulfill unmet needs for counseling, institutional policy and intervention should be implemented and innovative student support programs should be shared across various campuses to promote academic success and happiness of students.

Acknowledgements: None.

Funding: None.

Conflicts of interest: None.

\section{REFERENCES}

1. Dahlin M, Joneborg N, Runeson B. Stress and depression among medical students: a cross-sectional study. Med Educ 2005; 39: 594-604.

2. Firth-Cozens J. Medical student stress. Med Educ 2001; 35: 6-7.

3. Dunn LB, Iglewicz A, Moutier C. A conceptual model of medical student well-being: promoting resilience and preventing burnout. Acad Psychiatry 2008; 32: 44-53.

4. Niemi PM, Vainiomaki PT. Medical students' distress: quality, continuity and gender differences during a six-year medical programme. Med Teach 2006; 28: 136-141.

5. Guthrie EA, Black D, Shaw CM, Hamilton J, Creed FH, Tomenson B. Embarking upon a medical career: psychological morbidity in first year medical students. Med Educ 1995; 29: 337-341.

6. Tyssen R, Vaglum P, Gronvold NT, Ekeberg O. Factors in medical school that predict postgraduate mental health problems in need of treatment. A nationwide and longitudinal study. Med Educ 2001; 35: 110-120.

7. Tyssen R, Vaglum P, Gronvold NT, Ekeberg O. Suicidal ideation among medical students and young physicians: a nationwide and prospective study of prevalence and predictors. J Affect Disord 2001; 64: 69-79.

8. Cleland J, Arnold R, Chesser A. Failing finals is often a surprise for the student but not the teacher: identifying difficulties and supporting students with academic difficulties. Med Teach 2005; 27: 504-508.

9. Sayer M, Chaput De Saintonge M, Evans D, Wood D. Support for students with academic difficulties. Med Educ 2002; 36: 643-650.

10. Stewart SM, Lam TH, Betson CL, Wong CM, Wong AM. A prospective analysis of stress and academic performance in the first two years of medical school. Med 
Hong Im Shin and Woo Taek Jeon : "I'm Not Happy, But I Don't Care": Help-Seeking Behavior, Academic Difficulties, and Happiness

Educ 1999; 33: 243-250.

11. Hunt J, Eisenberg D. Mental health problems and help-seeking behavior among college students. J Adolesc Health 2010; 46: 3-10.

12. Eisenberg D, Golberstein E, Gollust SE. Help-seeking and access to mental health care in a university student population. Med Care 2007; 45: 594-601.

13. Malik S. Students, tutors and relationships: the ingredients of a successful student support scheme. Med Educ 2000; 34: 635-641.

14. Givens JL, Tjia J. Depressed medical students' use of mental health services and barriers to use. Acad Med
2002; 77: 918-921.

15. Tjia J, Givens JL, Shea JA. Factors associated with undertreatment of medical student depression. J Am Coll Health 2005; 53: 219-224.

16. Hills P, Argyle M. The Oxford Happiness Questionnaire: a compact scale for the measurement of psychological well-being. Pers Individ Dif 2002; 33: 1073-1082.

17. Durning SJ, ten Cate OT. Peer teaching in medical education. Med Teach 2007; 29: 523-524.

18. Sobral DT. Cross-year peer tutoring experience in a medical school: conditions and outcomes for student tutors. Med Educ 2002; 36: 1064-1070. 